TECHNICAL SCIENCES AND TECHNOLOGIES

UDC (07) $621.7,621.8$

DOI: $10.25140 / 2411-5363-2018-4(14)-101-108$

\author{
Peter Tuleja, Michal Demko
}

\title{
ANALYSIS OF THE ASPECTS THAT DETERMINE THE SELECTION OF THE DRIVE SYSTEM FOR A VEHICLE DRIVEN BY COMPRESSED AIR
}

Urgency of the research. Activities in the field of compressed air drive unit design are the subject of research into alternative energies for automotive drive. The competition mentioned in this article is intended to stimulate universities and high school students to make material outcomes in this area of research. These activities bring new, sometimes unconventional solutions to problems that can potentially bring about solutions applicable in technical practice.

Target setting. The aim of this article was to map out possible ways of realizing a drive unit of a vehicle that is driven by compressed air. Based on an analysis of the most commonly used ways of solving this problem, the article indicates the direction of development of such a drive unit.

Actual scientific researches and issues analysis. Research in this area consists in designing a drive unit that would allow dynamic driving at low compressed air consumption. This requires the perfect mastering of the theoretical knowledge about recirculation in compressed gas as well as the optimization of the power parameters of the unit by appropriate design of the basic construction component - linear pneumatic drive.

Uninvestigated parts of general matters defining. Only one group of transformation mechanisms is analyzed in the article that allow the compressed air drive unit to be constructed.

The research objective. The aim of the research is to provide a theoretical and mathematical basis for determining the optimum parameters of a compressed air propelled vehicle unit as well as its application for the construction of new vehicles for competition.

The statement of basic materials. The basic material for the creation of the article was taken from the bachelor thesis of the co-author of the article [3], from the contest proposals and other sources available in the library and magazine materials as well as from the prepared study materials for the students of the Technical University of Kosice, Slovakia.

Conclusions. Conclusions of the article lead to the determination of the appropriate concept of transformation of linear motion of the pneumatic drive to rotational in order to achieve the best results in the next year of the International Aventics Pneumobile Competition.

Keywords: drive system; vehicle; compressed air; pneumatic components, consumption, power, force, torque.

Fig.: 9. Table: 1. References: 10.

\section{Introduction}

If it's built problem of replacing fossil fuels in the car of their compensation with electric propulsion units, it is not quite true.

The development was reported in the use of hydrogen. The experiment was carmaker Citroen unveiled a hybrid car, which in addition to the internal combustion engine is driven by the compressed air prepared in time using an internal combustion engine, respectively. using the kinetic energy of the moving car (use of vehicle kinetic energy to compress air). Qualitative new form of use of compressed air was provided by the Luxembourg company MDI (Moteur Developpment International), which in its concept called AirPod has a modified piston engine (Fig. 4), which is driven by compressed air from a tank in which the pressure reaches $24.8 \mathrm{MPa}$. The air from the surrounding environment is sucked into the pistons and is pressed to raise the temperature to approximately $400^{\circ} \mathrm{C}$. Subsequently, relatively cool compressed air is injected from the tank; this is in hot air rapidly expands and thereby drives the piston $[1 ; 3]$.

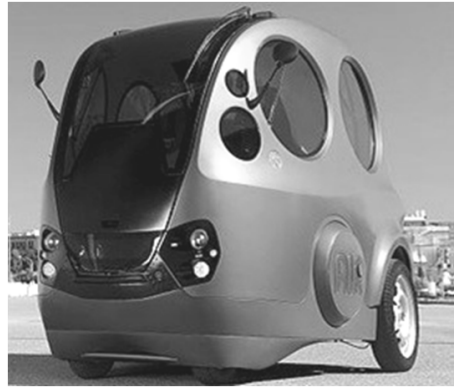

$a$

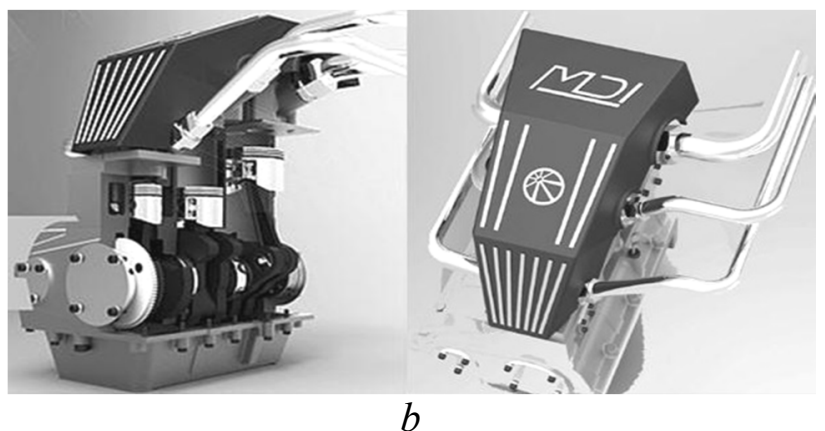

$b$

Source: $[1 ; 3]$.

Fig. 1. MDI car AirPod (a) and its drive unit (b)

(C) Tuleja P., Demko M., 2018 
AVENTICS Company (successor to pneumatic Bosch Rexroth division) in 2019 organizes already the 12-th annual competition for students of secondary schools of technical field named International Aventics Pneumobile Competition, where students will compete for the best placement in 4 basic categories:

- Long-distance race

- Arcade races

- Acceleration race

- Team Presentations

The vehicle that the students enter into the competition must be placed within the specified time. The pneumatic components used in its construction must be exclusively from AVENTICS [2]. The drive unit of the vehicle must be made up to a maximum of 4 linear pneumatic actuators, the dimensions of which are given in Table.

Table

Permitted dimensions of pneumatic drive AVENTICS PRA series [9]

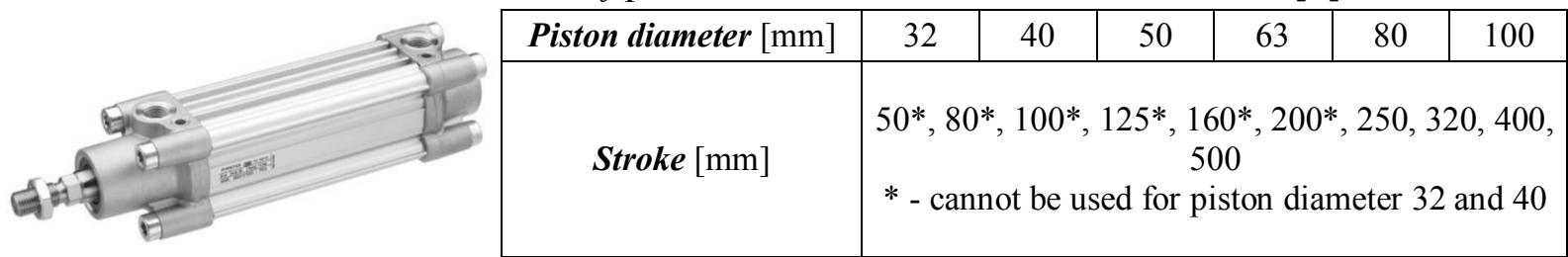

Rotary drives are forbidden. This means that students must devise a way to optimally transform the force of a linear pneumatic drive into a torque.

However, they must do so at the maximum torque to use a minimum volume of compressed air. Other pneumatic components of AVENTICS may also be used. Their selection can be made either from the competition catalog or from AVENTICS main catalog, or other cooperating companies (BOSCH Rexroth, National Instruments, Emerson). Approved components are provided by AVENTICS Hungary Kft., others are paid for by the participant himself.

The compressed air source for each team is a bottle filled with pressurized nitrogen with a volume of 10 liters at a pressure of $20 \mathrm{MPa}$ (200 bar). The maximum pressure applicable to the drive unit and the pneumatic circuit is generally $1 \mathrm{MPa}(10 \mathrm{bar})$. The pressure level is provided by the regulator without air venting, Fig. 2. Therefore, every vehicle in its pneumatic circuit must necessarily be assigned EMEGRENCY-STOP SWITCHING as protection against dangerous overpressure in the circuit, Fig. 2.

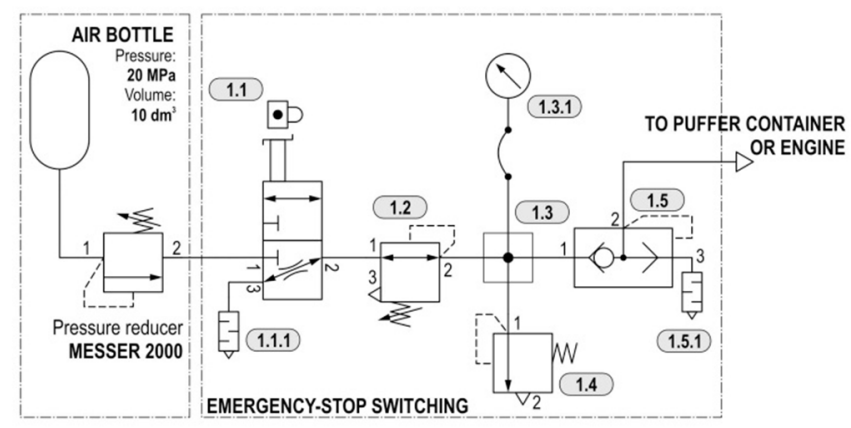

$a$

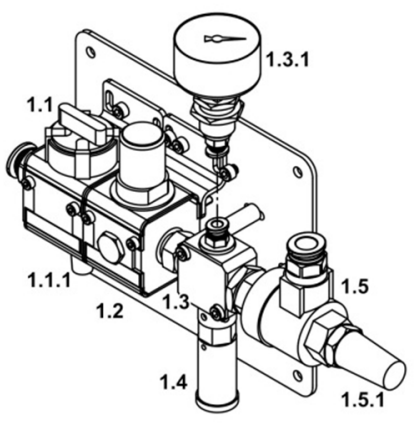

$b$

Fig. 2. Pneumatic circuit diagram of the vehicle's pneumatic circuit at the inlet (a) and its picture after assembling (b)

Source: [2].

Since the volume of usable compressed air is limited, and also the limited maximum usable pressure compressed air used only optimization concept powertrain (engine) of the pneumobil is possible to achieve a competitive result. 
TECHNICAL SCIENCES AND TECHNOLOGIES

From the next analysis, it will be clear that it is not possible to build a vehicle that would win all competitions.

\section{Compressed air consumption}

Total compressed air consumption during engine operation and pneumatic circuit protection circuits will mainly limit the result of part of the competition Long Distance Race.

To calculate the specific volume of compressed air we start from the Boyle-Mariotte law [5]:

$$
p_{1} \cdot V_{1}=p_{2} \cdot V_{2}
$$

where $p_{1}$...pressure before compression [MPa] $\quad V_{1} \quad \ldots$ volume before compression

$p_{2} \quad \ldots$ pressure after compression $(20 \mathrm{MPa}) \quad V_{2} \quad \ldots$ volume after compression $(10 l)$

By modifying equation (1) for a range of useful pressures can be determined usable volume of compressed air, Table 2.

Table 2

The values of usable compressed air at a selected pressure value [5]

\begin{tabular}{|c|c|c|}
\hline & Air pressure in system $\boldsymbol{p}_{\boldsymbol{1}}[\mathrm{MPa}]$ & Usable volume $\boldsymbol{V}_{\boldsymbol{I}}\left[\mathrm{dm}^{3}\right]$ \\
\hline $\mathbf{1}$ & 1,0 & 200,00 \\
\hline $\mathbf{2}$ & 0,9 & 222,22 \\
\hline $\mathbf{3}$ & 0,8 & 250,00 \\
\hline $\mathbf{4}$ & 0,7 & 285,71 \\
\hline $\mathbf{5}$ & 0,6 & 333,33 \\
\hline $\mathbf{6}$ & 0,5 & 400,00 \\
\hline $\mathbf{7}$ & 0,4 & 500,00 \\
\hline $\mathbf{8}$ & 0,3 & 666,67 \\
\hline
\end{tabular}

Air consumption for double-acting linear drives can be calculated according to the relationship [5]:

$$
Q=S \cdot L \cdot n
$$

where $Q \quad \ldots \quad$ air consumption of drive $\left[1_{\mathrm{N}} \cdot \mathrm{min}^{-1}\right]$;

$S \ldots$ the piston area of the drive $\left[\mathrm{mm}^{2}\right]$;

$L \quad \ldots \quad$ length of drive path of the drive (drive stroke) $[\mathrm{mm}]$;

$n \quad \ldots \quad$ number of cycles per minute $\left[\mathrm{min}^{-1}\right]$.

For one cycle while considered full extension and retraction of the piston (rod).

Table 3

Average air consumption at $1 \mathrm{MPa}$ at one double cylinder stroke [3]

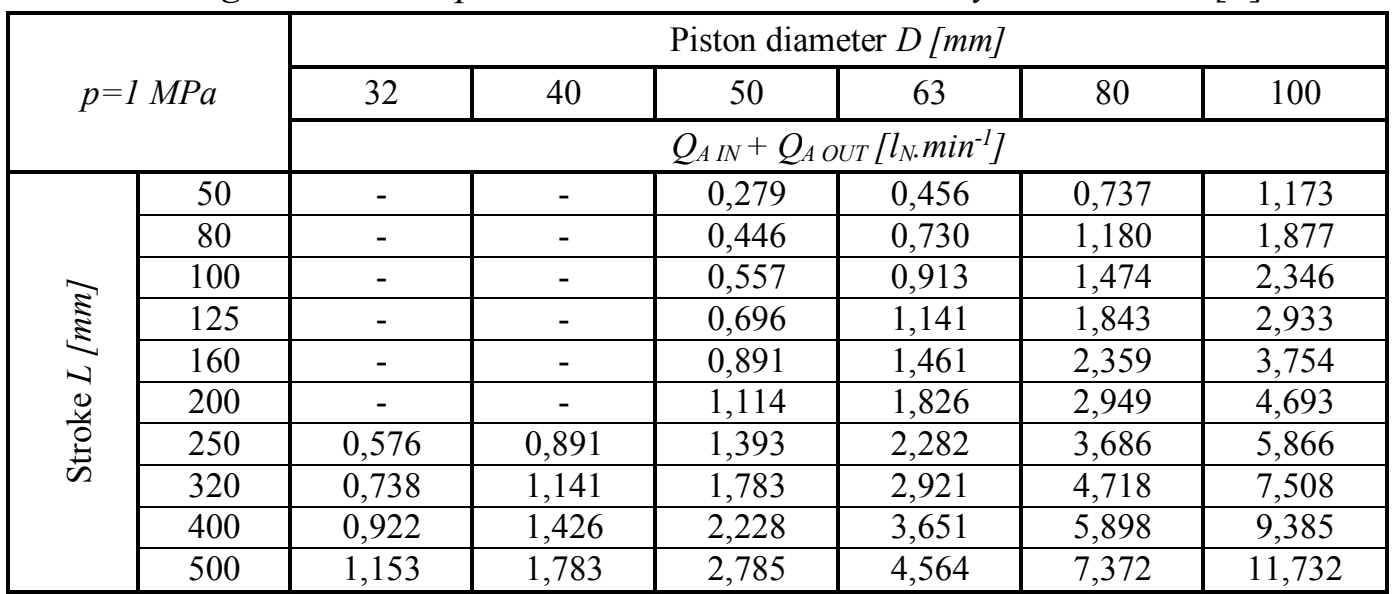


Then the average air consumption is given by:

$$
Q_{A}=Q_{A I N}+Q_{\text {AOUT }}=k \cdot \frac{\pi \cdot\left(D^{2}-d^{2}\right)}{4} L \cdot \frac{(p+0,10135)}{10^{5}} n_{I N}+k \cdot \frac{\pi \cdot D^{2}}{4} L \cdot \frac{(p+0,10135)}{10^{5}} n_{\text {OUT }}
$$

where $k=1,4$ is the coefficient reflecting the thermodynamic changes in the drive operation.

For accurate calculation, it is also necessary to take into account the air that circulates through the hoses [3]

$$
Q_{A T}=k \cdot \frac{\pi \cdot d_{T}^{2}}{4} L \cdot \frac{p}{10^{5}} n
$$

where $d_{T}$ is the inside diameter of the hose and $L$ is its length.

To determine the appropriate valve, coupling size and connection hose diameters to the drive, it is necessary to calculate the instantaneous maximum air consumption $Q_{O}\left[1_{\mathrm{N}} \cdot \mathrm{min}^{-1}\right]$

$$
Q_{o}=k \cdot \frac{\pi \cdot D^{2}}{4} v \cdot \frac{(p+0,10135) \cdot 60}{10^{5}}
$$

It is clear from this that when constructing the drive unit, we must carefully handle both the diameter and stroke of one drive as well as their number.

It is obvious that the total air consumption will also be strongly dependent on the drive speed. This parameter is limited by the used supply valve (flow rate) as well as the diameter and length of the hoses used.

\section{Force versus torque}

For Arcade Races and Acceleration race, the decisive criterion is not the consumption of compressed air, but the power of the drive unit, that is, sufficient torque. This parameter is based on the maximum achievable force of linear pneumatic drives used and on the principle of linear motion transformation to rotational. Obviously, the designer will be interested in the power of the drive.

For a linear double-acting pneumatic drive, it is expressible by a relationship [5]

$$
F_{T}=S \cdot p
$$

where $F_{T}$ is the theoretical force of the linear drive [N];S is the area of the piston $\left[\mathrm{m}^{2}\right] ; p$ is the working pressure of the compressed air in the circuit $[\mathrm{Pa}]$.

For single-piston linear double-acting drive, Fig. the drive force is greater than the force when the piston is pulled out. When pulling the piston, the relationship applies:

$$
F_{\text {OUT }}=\frac{\pi}{4} D^{2} \cdot p
$$

and when the piston is pushed, is valid

$$
F_{I N}=\frac{\pi}{4}\left(D^{2}-d^{2}\right) \cdot p
$$

when $D$ is piston diameter [m], $d$ is piston rod diameter [m], $p$ is working pressure [Pa].

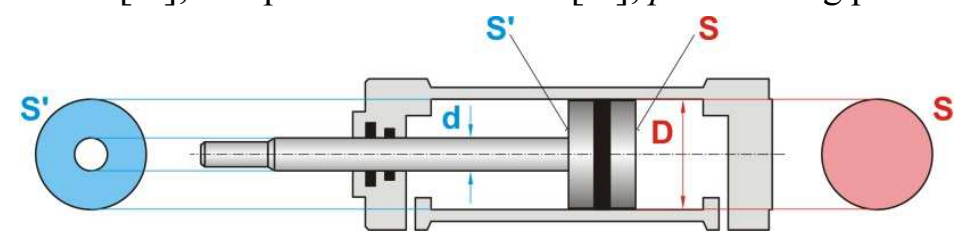

Fig. 3. Force ratios on double-acting linear drive

Table 4

Theoretical forces of drives usable for engine construction [3]

\begin{tabular}{|c|c|c|c|c|c|c|}
\hline \multirow{2}{*}{$p=1 \mathrm{MPa}$} & \multicolumn{7}{|c|}{ Piston diameter $D[\mathrm{~mm}]$} \\
\cline { 2 - 7 } & $\mathbf{3 2}$ & $\mathbf{4 0}$ & $\mathbf{5 0}$ & $\mathbf{6 3}$ & $\mathbf{8 0}$ & $\mathbf{1 0 0}$ \\
\hline$F_{\text {OUT }}[N]$ & 804 & 1257 & 1963 & 3117 & 5027 & 7854 \\
\hline$F_{I N}[N]$ & 691 & 1056 & 1649 & 2803 & 4536 & 7363 \\
\hline
\end{tabular}


TECHNICAL SCIENCES AND TECHNOLOGIES

Drive efficiency80-95\% varies between 80-0,95\%. This value depends strongly on the drilling diameter of drive and the working pressure. The upper limit applies to larger drilling diameters and higher working pressures [5].

Using the transformation of a linear to rotary motion by a crank mechanism [3], Fig. 4, is the resulting torque $M_{K}$ by angle of rotation $\alpha$ :

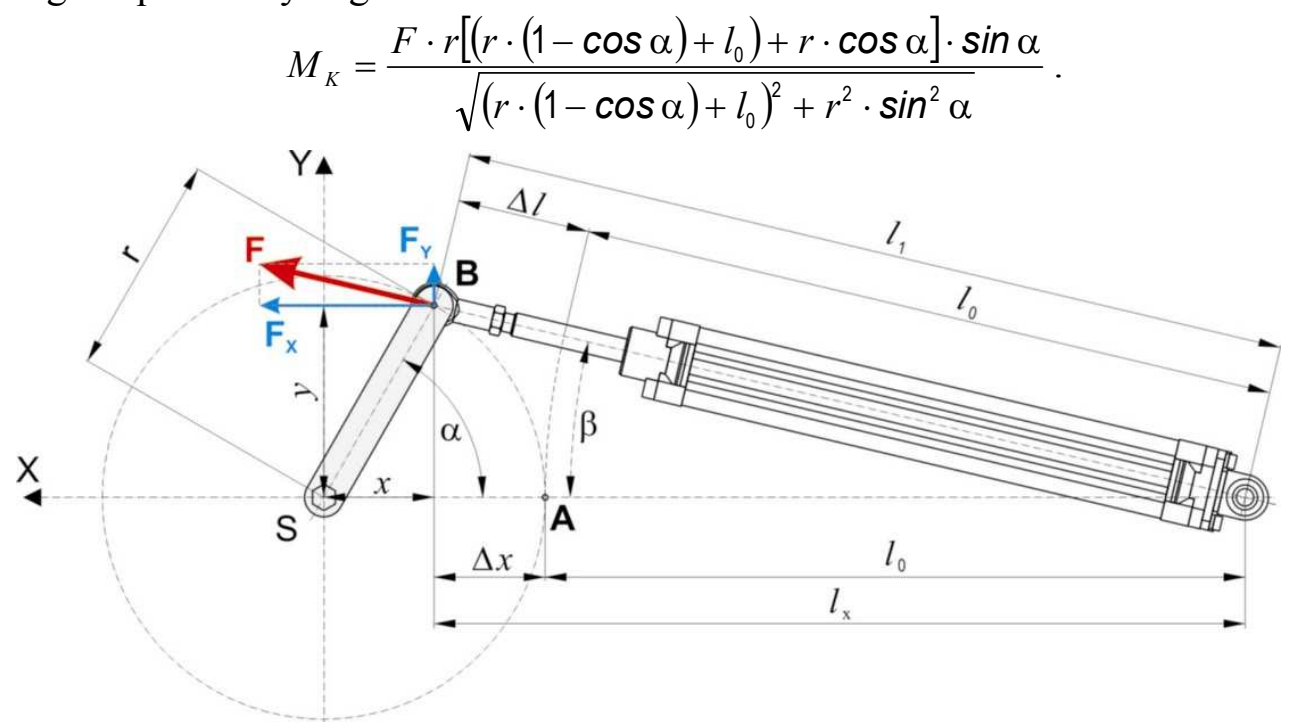

Source: [3].

Fig. 4. Ratios on crank mechanism

Because the force of the double-acting linear cylinder is different when pulling and pushing the piston rod, for $\alpha \subset\left\langle 0^{\circ}, 180^{\circ}\right\rangle$ is valid:

$$
M_{K}=\frac{F_{\text {OUT }} \cdot r\left[\left(r \cdot(1-\cos \alpha)+l_{0}\right)+r \cdot \cos \alpha\right] \cdot \sin \alpha}{\sqrt{\left(r \cdot(1-\cos \alpha)+l_{0}\right)^{2}+r^{2} \cdot \sin ^{2} \alpha}}
$$

and for $\alpha \subset\left\langle 180^{\circ} ; 360^{\circ}\right\rangle$ is valid:

$$
M_{K}=\frac{F \cdot r\left[\left(r \cdot(1-\cos \alpha)+l_{0}\right)+r \cdot \cos \alpha\right] \cdot \sin \alpha}{\sqrt{\left(r \cdot(1-\cos \alpha)+l_{0}\right)^{2}+r^{2} \cdot \sin ^{2} \alpha}}
$$

The crank radius $r$ can be selected arbitrarily with a maximum value equal to half the stroke of the cylinder. Torque dependency graph created by one pneumatic cylinder depending on the crankshaft angle at the diameter of the cylinder bore $50 \mathrm{~mm}$, at the diameter of the piston rod $20 \mathrm{~mm}$ and at the stroke $200 \mathrm{~mm}$ (crank radius $100 \mathrm{~mm}$ ) is in Fig. 5.
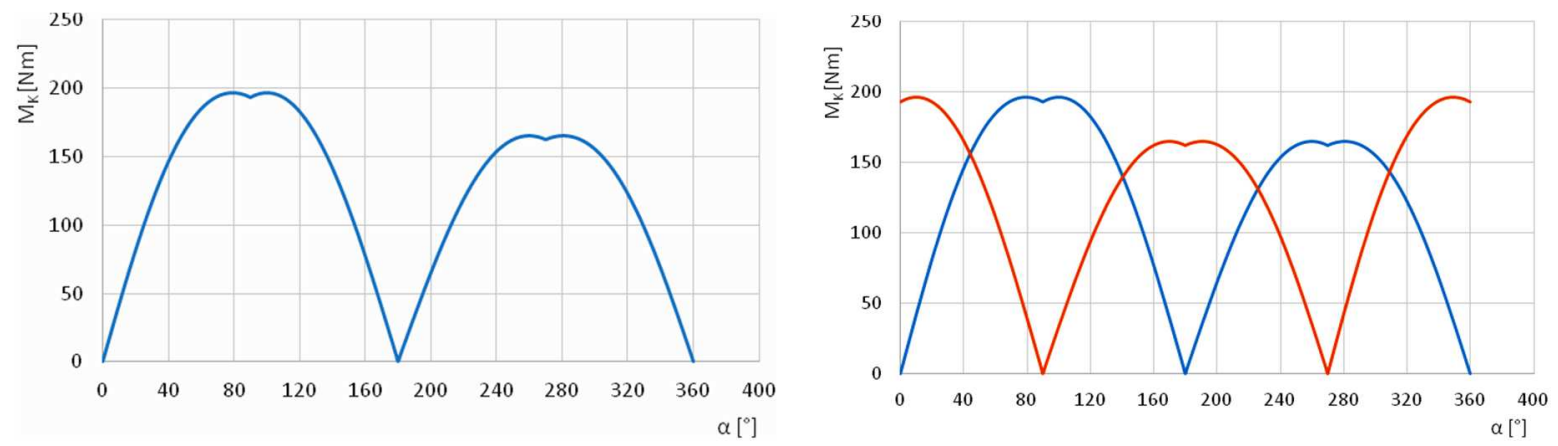

Source: [3].

Fig. 5. Ratios on crank mechanism [3] 
TECHNICAL SCIENCES AND TECHNOLOGIES

The very concept of transforming the linear force to the torque is not limited. There are several proven forms available:

crank mechanism (with one to four actuators with different arrangements)

1.1 two, Fig. 6a, or four actuators next to each other, Fig. 6b;

1.2 one to four actuators above myself, Fig. $6 \mathrm{c}$;

1.3 three drives arranged in the star, Fig. $6 \mathrm{~d}$.

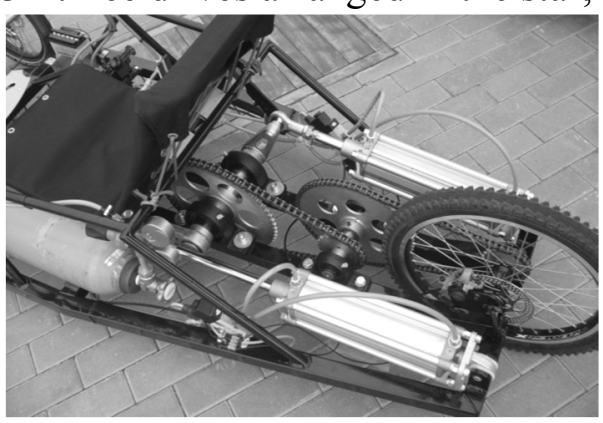

$a$

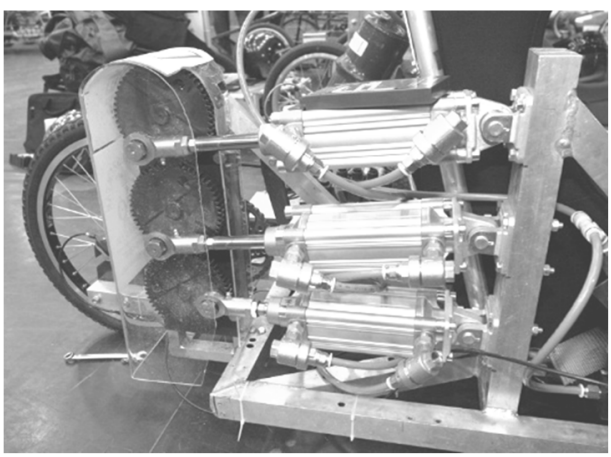

C source $[10]$

source [8]

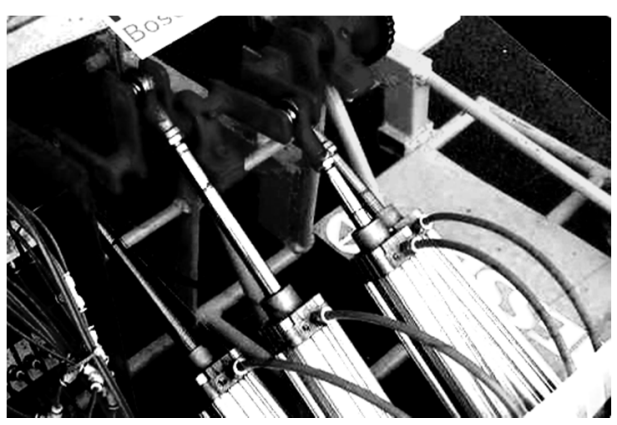

source [8]

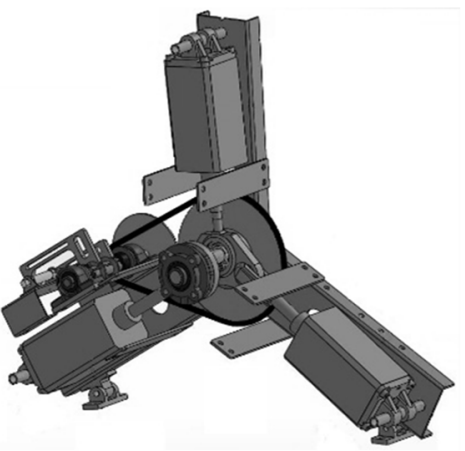

$d$

source [7]

Fig. 6. Examples of drive units utilizing a crank mechanism

the rack and pinion (pinions)

2.1 a pair of pinions above the other, Fig. $7 \mathrm{a}$;

2.2 a pair of pinions behind, Fig. $7 b$.

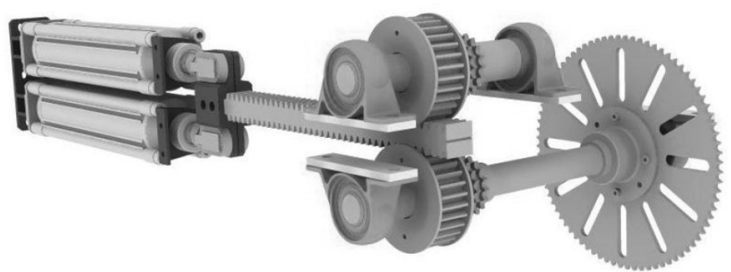

$a$

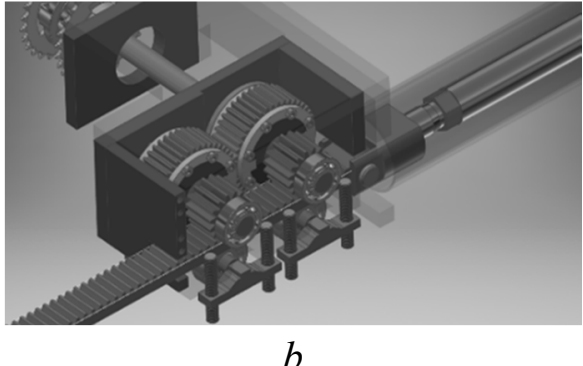

$b$

Fig. 7. Examples of drive units utilizing a rack-pinion pair: $a-a$ pair of pinions above the other [6], $b-a$ pair of pinions behind [4]

chain mechanism, Fig. 8;

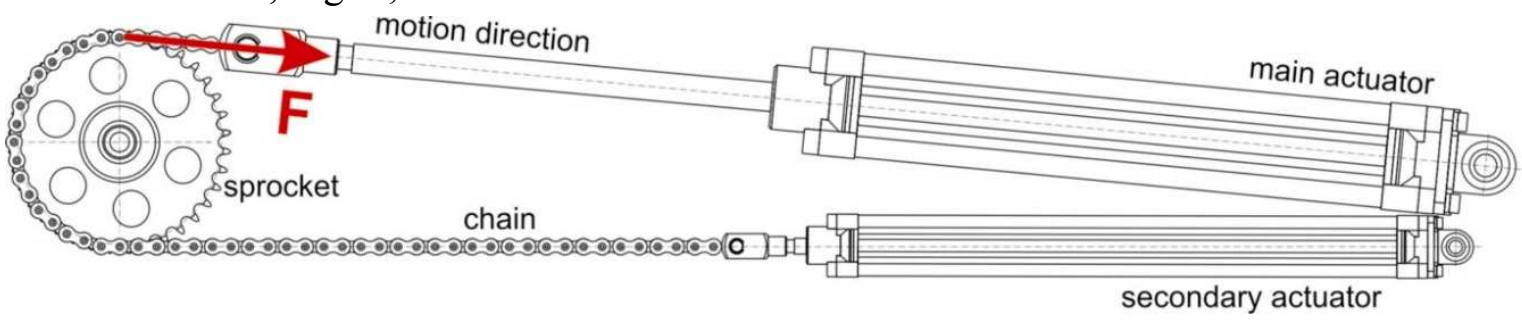

Fig. 8. The principle of a drive unit that utilizes a chain mechanism [3] 
TECHNICAL SCIENCES AND TECHNOLOGIES

axial mechanism, Fig. 9.

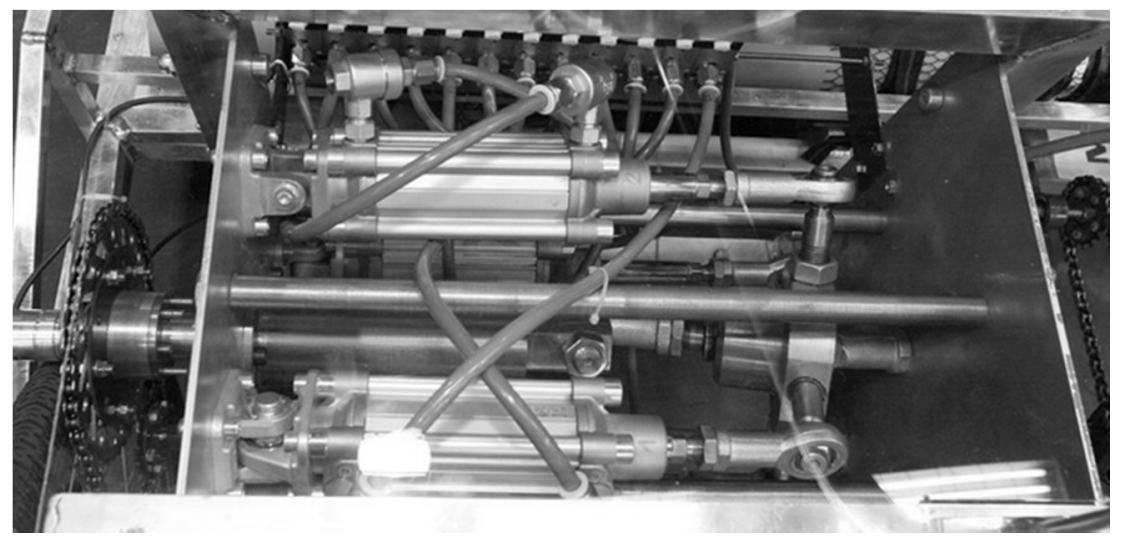

Fig. 9. Example of a drive unit utilizing an axial mechanism [8]

Conclusion. Therefore, the question of optimal selection of a suitable linear pneumatic drive is the question of vehicle designers. To select applies restrictive criterion set out in Table 1. Based on the experience of participating in the race, the vehicles used to transform the linear movement into a rotary way by means of a pair of rack-pinion were the most used of the concepts.

This concept for the next year is also planned by one of our faculty teams. We believe that the abilities of our students will lead to an improvement in the placement from the last year of the International Aventics Pneumobile Competition.

This contribution is the result of the project implementation: Research modules for intelligent robotic systems (ITMS: 26220220141) supported by the Research \& Development operational Program funded by the ERDF.

\section{References}

1. Air Volution Ltd : MDI Compressed Air Engine. [online]. [cit. 2018-05-07]. Available on the Internet: http://www.air-volution.com.au/technology/compressed-air-engine/

2. Aventics Hungary Kft.: Announcement and rules, XII. International Aventics Pneumobile Competition $2019-$ powered by Emerson, Available on the Internet: http://en.pneumobil.hu/pneumobile_2019/announcement_and_rules/announcement_and_rules_2019

3. Demko, M., Tuleja P.: Analýza hnacej sústavy pre vozidlo poháňané stlačeným vzduchom (Analysis of drive system for a vehicle powered by compressed air). Bachelor thesis. Technical university of Košice, Košice 2018, 50 pp., (in Slovak)

4. Hajda, J.: Evolventni ozubení. [online]. [cit. 2018-05-10] (in Czech). Available on the Internet: http://forum.strojirenstvi.cz/download/file.php?id=83674

5. Hajduk, M., Tuleja, P.: ZÁKLADY PNEUMATICKÝCH MECHANIZMOV I.: Výroba, úprava a rozvod stlačeného vzduchu a vákua, Technická univerzita v Košiciach, Košice 2013, ISBN 978-80-553-1605-5, (in Slovak)

6. Navrátil, L., Ranuš, M.: Analýza a optimalizace pneumatického systému závodního pneumobilu. Bachelor thesis. Vysoké učení technické v Brně, Fakulta strojního inženýrství, Brno 2016. (in Czech)

7. Palko, M., Tuleja, P.: Návrh experimentálneho vozidla poháňaného stlačeným vzduchom (Design of an experimental compressed air powered vehicle). Diploma thesis. Technical university of Košice, Košice 2018, 70 pp., (in Slovak)

8. Pneumobil.hu: Gallery. [online]. [cit. 2018-05-10]. Available on the Internet: http://en.pneumobil.hu/introduction/history

9. Profile cylinder ISO 15552, Series PRA, Datasheet. Available on the Internet: https://www.aventics.com/pneumatics-catalog/Configuration/?Language=en\&Variant= internet\&file $=$ en/pdf/PDF_p8771_en.pdf

10. Sodolák, M., Nevrlý, J.: Teoretické řešení pneumobilu. Diploma thesis. Vysoké učení technické v Brně, Fakulta strojního inženýrství, Brno 2011 (in Czech). 


\author{
Петер Тулейа, Міхал Демко
}

\title{
АНАЛІЗ АСПЕКТІВ, ЩО ВИЗНАЧАЮТЬ ВИБІР СИСТЕМИ ПРИВОДА ДЛЯ ТРАНСПОРТНОГО ЗАСОБУ, ЩО ПРИВОДИТЬСЯ В РУХ СТИСНЕНИМ ПОВІТРЯМ
}

Актуальність теми досліджсеня. Діяльність в області проектування приводів стисненого повітря є предметом дослідження альтернативних джерел енергї для автомобільного приводу. Конкурс, згаданий у иій статті, покликаний стимулювати університети і старшокласників до досягнення матеріальних результатів у иій галузі досліджень. Ці дї приносять нові, іноді нетрадиційні рішення проблем, які можуть потенційно привести до рішень, щуо можуть застосовуватися в технічній практиці.

Постановка проблеми. Метою иүієі статті було намітити можливі иляхи реалізацї вузла приводу транспортного засобу, який приводиться в рух стисненим повітрям. На основі аналізу найбільш часто використовуваних способів вирішення иієї проблеми в статті вказується напрямок розвитку такого приводу.

Аналіз останніх досліджень і публікацій. Дослідження в иій сфері полягають у розробиі приводу, який дозволяв би динамічне водіння при низькому споживанні стисненого повітря. Це вимагає ідеального засвоєння теоретичних знань про рециркуляиії в стиснутому газі, а також оптимізації енергетичних параметрів агрегату шляхом відповідної конструкиї основного конструктивного елемента - лінійного пневматичного привода.

Виділення недосліджених частин загальної проблеми. У статті проаналізовано тільки одну групу перетворюючих механізмів, які дозволяють створити приводний агрегат на стисненому повітрі.

Постановка завдання. Метою дослідження є забезпечення теоретичної та математичної основи для визначення оптимальних параметрів самохідного агрегату з двигуном на стиснутому повітрі, а також його застосування для створення нових транспортних засобів для змагань.

Виклад основного матеріалу. Основний матеріал для створення статті було взято з дипломної роботи співавтора статті [3], з конкурсних пропозицій та інших джерел, доступних у бібліотеці, і журнальних матеріалів, а також з підготовлених навчальних матеріалів для студентів Технічного університету Кошице, Словаччина.

Висновки відповідно до статmі. Стаття веде до визначення підходящої концепції перетворення лінійного руху пневматичного приводу у обертальний з метою досягнення найкращих результатів у наступному році на Міжнародному конкурсі пневматичних автомобілів Aventics.

Ключові слова: система приводу; транспортний засіб; стиснене повітря; пневматичні компоненти; витрата; потужність; сила; крутний момент.

Рис.: 9. Табл.: 1. Бібл.: 10.

Tuleja Peter - Eng., PhD, assistant professor, Technical university in Kosice, Faculty of Mechanical Engineering, Institute of Automatization, Mechatronics and Robotics, Department of Robotics, Komenskeho Park 8 , 04200 Kosice, Slovakia

E-mail: peter.tuleja@tuke.sk

Scopus Author ID: 55570858300

Demko Michal - Bc., student, Technical university in Kosice, Faculty of Mechanical Engineering, Institute of Automatization, Mechatronics and Robotics, Department of Robotics, Komenskeho Park 8, 04200 Kosice, Slovakia E-mail: demko.misko@gmail.com

Tuleja, P., Demko, M. (2018). Analysis of the aspects that determine the selection of the drive system for a vehicle driven by compressed AIR. Technical sciences and technologies, 4 (14), 101-108. 